\title{
THE CONTENT OF CHEMICAL ELEMENTS IN ARCHAEOLOGICAL HUMAN BONES AS A SOURCE OF NUTRITION RESEARCH
}

\author{
RAILI ALLMÄE ${ }^{1}$, JANA LIMBO-SIMOVART ${ }^{1}$, \\ LEIU HEAPOST ${ }^{1}$, EVELIN VERS $\check{S}^{2}$ \\ ${ }^{1}$ Institute of History, Tallinn University, Estonia \\ ${ }^{2}$ Institute of Geology, Tallinn University of Technology, Estonia
}

\begin{abstract}
The aim of the present research was to determine chemical elements using the inductive plasma mass spectrometer (ICP-MS) in Estonian archaeological human bones to establish the possible content of the menu in different communities.

Among the studied material clear differentiation can be made between the Pärnu cemetery of St John's church (the cemetery of the Pärnu garrison) from the $16-18^{\text {th }} \mathrm{cc}$. and the Tääksi village cemetery from the $14-18^{\text {th }}$ century. The material from the $12-13^{\text {th }} \mathrm{cc}$. Pada cemetery remains between the two abovementioned cemeteries concerning the content of the observed elements.

The initial data show only the differences of the general trends of the content of chemical elements between the inland and the coastal areas, the village and the town, the higher and the lower social status communities. The contents of chemical elements in the Estonian archaeological bones were similar to the respective contents in Latvia.
\end{abstract}

Key words: palaeodiet, trace elements, Estonia, the Late Iron Age, the Middle Ages, the Modern Times 


\section{INTRODUCTION}

The information about the diet of historical populatons can be obtained from very different sources like the historical documents, finds, which are connected with the production or processing of food, archaeobotanical and zoological materials and archaeological human remains.

The nutrition of people in the past can be studied with the help of chemical analyses of human bones. The first attempts to reconstruct the diet of the people in the past on the basis of the content of chemical elements in the bones were made in the second half of the $20^{\text {th }}$ century, Brown (1973) [12] and Gilbert (1975) [23] being the pioneers. The research trend was especially intensive in the 1980s. The contents of different chemical elements and their relationships allow the researcher to study, which the people's food was in different historical periods and areas.

Calcium (Ca) is one of the main parts of the mineral component in the bones. The bone's mineral part consists of a most stable mineral hydroxyapatite in which the calcium content is quite stable (about 38\%). The measurement of the calcium content in microanalyses is mainly made with the purpose of assessing the quality of the material. In the case of the fully preserved collagen, the Ca content varies to the degree of $26 \%-38 \%$ [14] in archaeological bones.

The contents of vanadium $(\mathbf{V})$, copper $(\mathbf{C u})$ and zinc $(\mathbf{Z n})$ in bones are considered to be the indicators of meat food [13]. For example, the organism, which uses more animal food (incl. fish, crustaceans, molluscs), always contains more zinc $(\mathbf{Z n})$. It is confirmed by the comparative studies of the zinc content in the bones of carnivores and herbivores. Here the only exception is nuts, containing also noteworthy amounts of zinc, in the plant food. Also, the people, in whose diet marine food has had a big role, may have a higher content of $\mathrm{Zn}$ in their bones than the people consuming the mainland food [24, 31]. The $\mathrm{Zn}$ content in the bones of a human being as an omnivore (including both animal and vegetable tissue in the diet) varies in the degree 50-826 ppm-i [7]. In principle, on the higher level of the trophic pyramid the organism is, the bigger is its $\mathrm{Zn}$ content in its bones and the smaller is the $\mathrm{Sr}$ content. The comparative analysis of the $\mathrm{Zn}$ content in the bones of omnivores should consequently reflect the relative proportion of the consumed meat food in the menu. When low $\mathrm{Zn}$ contents are equal to the higher Sr contents, it may be supposed that the community consumed a smaller amount of meat [19]. 
The main foodstuffs containing copper $(\mathbf{C u})$ are liver, red meat, fish meat, beans, peas, products of full cereals, nuts. In the organisms of carnivores there is always more copper than in herbivores [24]. Also, crustaceans and molluscs contain much copper [35]. The major products containing vanadium (V) are liver, plant and animal lipids. For example, high contents of vanadium are in the fresh vegetables like parsley, dill, radish, lettuce, in the berries like strawberries and in fatty fish and the fish liver [51]. When the established indicators of $\mathrm{Zn}$ and $\mathrm{Cu}$ in bones are high, then, as a rule, together with them the content of $\mathrm{V}$ is high because animal fat contains $\mathrm{V}$ [13].

The indicators of plant food in bones are considered to be the contents of manganese (Mn), barium (Ba), and strontium ( $\mathrm{Sr}$ ) [49].

The best sources of manganese (Mn) are plant foodstuffs. The content of manganese in them depends on the soil they have grown on [26]. Manganese cannot almost be found in meat, chicken, fish, milk and milk products but it is in big quantities in legumes, green vegetables, cereals, especially in wheat sprouts, whole-meal bread, nuts. The manganese content in bones is considered to be a good indicator in assessing the proportions of plant food [49] but contrary conclusions have also been made [33].

The strontium ( $\mathbf{S r}$ ) content in bones is considered to be the indicator of plant food. Plants get strontium from the soil, this is how strontium enters substance chain. The plants, having grown on carbonate soils, are especially rich in strontium [34]. There is relatively much strontium in spices, in green vegetables, root crops, cereals, beans, peas, lentils and also marine food. $99 \%$ of the strontium in the organisms of vertebrates is in the inorganic content of bones [8]. By its structure strontium is similar to calcium and can replace calcium in the inorganic part of bones - in hydroxyapatite. As it is known, in the human organism strontium does not have a definite physiological role and the organism processes it similar to calcium. In the bones of omnivores, including human beings, the smaller the relative content of $\mathrm{Sr}$, the bigger is the proportion of meat in their food. The situation becomes more complicated in the marine environment because the concentrations of $\mathrm{Sr}$ are bigger in the sea water and the marine food [34]. In the research of the paleodiet Sr contents are also used for distinguishing marine and inland nutrition [18].

In nature barium (Ba) can be found in cereals, potato, milk and to a certain degree in algae and fish. In the organisms of vertebrates $90 \%$ of $\mathrm{Ba}$ is in the bones. As it is known, $\mathrm{Ba}$ in the organism does not have a clear biological function [45]. Similar to strontium also Ba may replace $\mathrm{Cu}$ in the mineral part 
of the bone. $\mathrm{Ba}$ is a thankworthy indicator of plant food in comparison with strontium because of two reasons. Firstly, it is less dependent on diagenesis. Secondly, if the high content of strontium in bones may be caused by the menu containing basically plant food and also the menu of marine food, then differently from strontium there is very litte barium in the sea water [41]. Higher contents of barium in bones are directly connected with plant food [49].

Relations between Ba and Sr. When the $\mathrm{Sr}$ contents are high in marine organisms, the $\mathrm{Ba}$ contents are low at the same time. Consequently, in the bones of the individuals, having mainly marine food, the $\mathrm{Ba} / \mathrm{Sr}$ relation is very low in spite of the fact whether $\mathrm{Ba}$ is from a plant or an animal source [42]. When the foodstuffs from the inland are added, the $\mathrm{Ba} / \mathrm{Sr}$ relation grows quickly because $\mathrm{Ba}$ contents in the food grown inland are always bigger. Burton and Price (1990) [15] recommended for distinguishing the marine nutrition (coastal agriculture and marine protein) and the inland nutrition (inland agriculture and terrestrial protein) to use the $\mathrm{Ba}$ and $\mathrm{Sr}$ logarithmic relation $(\log \mathrm{Ba} / \mathrm{Sr})$. The values of $\log \mathrm{Ba} / \mathrm{Sr}$ which are smaller than -1.40 refer to the fact that the community's diet is mainly based on marine food. The values of $\log \mathrm{Ba} / \mathrm{Sr}$ which are equal or higher than -0.40 show that the community mainly consumed foodstuffs from the inland.

Lead $(\mathbf{P b})$ does not have an important role in nutrition, it is rather harmful for the human organism. The content of lead in the bones refers to the influence of the surrounding environment. Lead gets into the organism either through the digestive tract or lungs and most of the lead getting into the organism is stored in the bones [11]. When the person gets older, the content of $\mathrm{Pb}$ in bones accumulates if the organism is exposed to the source of pollution. Biologically $\mathrm{Pb}$ behaves in the organism similar to $\mathrm{Sr}$ and $\mathrm{Ba}$ replacing calcium in the mineral part of the bone [14].

The people who lived in towns in the Middle Ages and the Early Modern Times have usually more lead in their bones than the people who lived in the rural areas. The appearance of lead in the organism is explained by the use of domestic vessels, which had the glazing containing lead, or the drinking water, which came from the pipelines containing lead $[17,49]$.

In interpreting the chemical composition of the archaeological bones there are also certain possibilities for making mistakes. It is well known that the chemical composition of the bones, which were in the soil for a long time, may have changed, the joint effect of the temporal factor and the environmental 
conditions playing a decisive role $[10,21,45,52]$. The cumulative effect of the physical, chemical and biological processes on the bones changing their chemical and physical composition is called diagenesis [54]. This is why in the recent years, in the nutrition research of archaeological population tooth dentine [16] has been used more often because thanks to the layer of enamel covering the tooth crown it is better protected from the other influence of the environment together with the geological, climatological and ground water characteristic features of the burial environment [52]. There are numerous studies of the diagenesis of bones in which the authors have tried to find a common scale for the assessment of the processes of diagenesis [21, 28, 45 etc]. With time the conclusion has been made that the diagenesis of each bone and skeleton is very specifically different, even within the same burial area, while the important role is played by early taphonomic factors or how human remains were treated before burial and the $\mathrm{pH}$ level of the soil is taken into consideration $[40,48]$.

The researcher must be careful in taking bone samples because different bones and also their parts may differ in the concentration of chemical elements $[49,43]$. It is also known that the compact substance of bones is modelled more slowly and it is more inert to the effects of the other environment because of its compact structure $[25,20]$ and this is why in taking samples the diaphysis of long bones should be preferred instead of taking ribs and flat bones because in them the sponge matter, being sensitive to pollution, is less protected. The chemical elements which are most often detected in the archaeological bones with the purpose of reconstructing the diet of the people in the past and the environmental effects are $\mathrm{Ca}, \mathrm{P}, \mathrm{Ba}, \mathrm{As}, \mathrm{Mg}, \mathrm{Sr}, \mathrm{Al}, \mathrm{Zn}, \mathrm{Mn}, \mathrm{Cu}, \mathrm{V}, \mathrm{Cd}, \mathrm{Cr}$ and $\mathrm{Pb}$ and also their interrelations are studied.

The aim of the present research is to study the contents of macro- and microelements in the archaeological bones with the inductive plasma mass spectrometer (ICP-MS) to assess the nutrition of ancient and historical populations from different areas in Estonia. Partially the results of the analysis have been interpreted already earlier [5]. Also, the results have been interpreted on the background of the studies, dealing with different food resources, relying as well as on the archaeological analysis and the research results based on historical sources [6]. We express our gratitude to a group of Latvian scientists whose research of the nutrition of the people in the past inspired us to carry out similar research in Estonia. In the present paper the contents of 
chemical elements of the Latvian archaeological bones have been used as a material for comparison [46].

\section{MATERIAL AND METHODS}

From the archaeo-osteological materials of Estonia three series were chosen for determing the content of chemical elements: $12^{\text {th }}-13^{\text {th }} \mathrm{cc}$. skeletons from the underground cemetery at the Pada ancient stronghold [53], $14^{\text {th }}-18^{\text {th }} \mathrm{cc}$. skeletons from the village cemetery at Tääksi [50] and $16^{\text {th }}-18^{\text {th }} \mathrm{cc}$. skeletons from the cemetery of St. John's church in Pärnu (the archaeologist Jaak Mäll, AGU-EMS 1998). In the choice of the material the researchers proceeded from the geographical, temporal and also possible life-style differences (Figure 1).

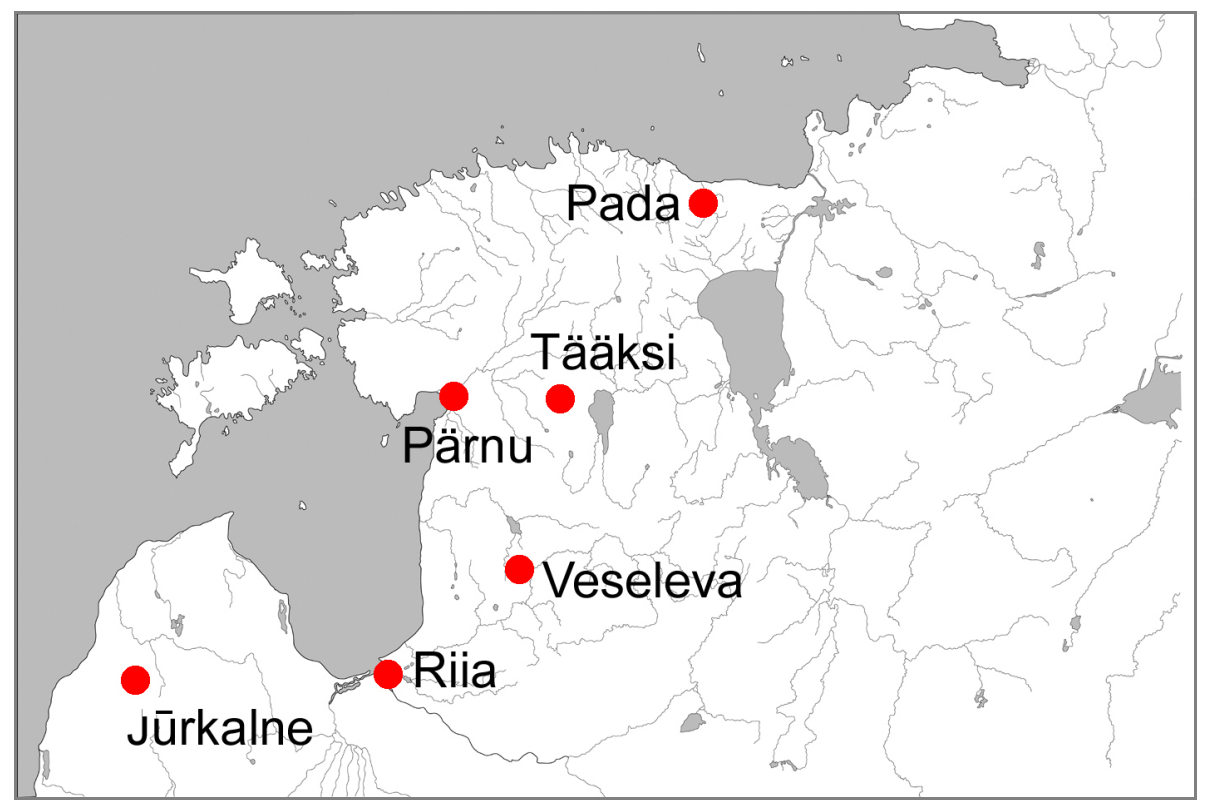

Figure 1. Estonian and comparative Latvian samples [46].

Most probably the local community was burying their dead in the Pada and the Tääksi cemeteries. The history of the cemetery of St. John's church in Pärnu is more complicated because it was closely connected with Swedish and Russian garrisons. Initially the Lutheran congregation used the cemetery of the St. John's church in Pärnu which was founded at the turn of the $16^{\text {th }}-17^{\text {th }}$ century. 
From the year 1617 Pärnu was under the rule of the Swedish power [32] and then the soldiers of the Pärnu garrison and the members of their families were buried in the cemetery. In the year 1710 the Pärnu garrison surrended to Russia, the membership in the Russian Empire brought the Russian garrison and the Russian Orthodox religion to Pärnu. In the year 1714 the St. John's church together with the cemetery was handed over to the Russian garrison [29]. The Orthodox crosses in big number were found during the archaeological study of the cemetery of St. John's church in Pärnu (Villu Kadakas, oral information to the authors).

In the chemical composition of the bone material from Tääksi, Pada and Pärnu there could appear differences which characterize the nutrition of the communities from three different areas and with a different social status. All the series of skeletons have been studied with different methods of physical anthropology in the recent $[1,27,3,2,36,37,4]$ and this is why the age and the gender of the buried are known. For the comparison of the situation in Estonia, the analysis of the Latvian $13^{\text {th }}-17^{\text {th }} \mathrm{cc}$. bone materials were used. The Latvian material consists of three series: the $13^{\text {th }}-17^{\text {th }} \mathrm{cc}$. St. Peter's churchyard in Riga, the $14^{\text {th }}-18^{\text {th }}$ cemetery in the Cesis district and the $16^{\text {th }}-17^{\text {th }}$ cc. Jurkalne cemetery in the Liepaja district [46].

From the skeleton series of Tääksi 28 adult skeletons (14 women and 14 men), from the Pada series 30 ( 15 men ja 15 women) and from the Pärnu series 31 ( 18 men ja 13 women) were chosen for chemical analyses. The bone samples were taken as a rule by drilling the right tibia's proximal part (min $5 \mathrm{mg}$ ). The surface bone layer was drilled off before collecting the material for the analysis. Samples were not taken from the bones which had evident traces of bronze objects. Further, the material was made into powder and $300 \mathrm{mg}$ of the test material was taken. The test material was weighed and put into the microwave oven's test vessel where concentrated ultrapurified acids were added (Fluka Analytical, Sigma-Aldrich Chemie GmbH, Germany): $4 \mathrm{ml}$ of $69-70 \% \mathrm{HNO}_{3}$ (with the purification level TraceSELECT ${ }^{\circledast}$ ) and $2 \mathrm{ml}$ of $30 \%$ $\mathrm{H}_{2} \mathrm{O}_{2}$ (with the purification level TraceSELECT ${ }^{\oplus}$ Ultra).

All the tests were processed with the microwave oven MW3000 (Anton Paar, Germany), using the rotor $16 \mathrm{HF} 100$ which is meant for the tests of hardly soluble materials (geological tests, metals, alloys, glass, quartz, polluted soil) to solve them because the rotor allows to use somewhat higher pressure $\left(\max 240^{\circ} \mathrm{C}\right)$ in comparison with other analogical rotors. All the processing was made using the similar parameters of power and time, heating the tests for 
40 minutes at the temperature ca $120^{\circ} \mathrm{C}$ and the pressure $35-40$ bar. After processing the reaction tubes were released from too much pressure (the pressure openings of corks were turned open) and some time was given for cooling. The tests were poured into the centrifuge cups and were diluted with ultraclean MilliQ water to the quantity of $50 \mathrm{ml}$.

The contents of micro- and macroelements in the test, received in the solution, were measured with the inductive plasma mass spectrometer (ThermoScientific X-Series 2 quadropool-ICP-MS) which was connected to the automatic input of tests Cetac AutoSampler ASX-520. As a measurement standard the International standard NIST-SRM 1486 (animal bone flour) and the multielement liquid standard Multi Element Solution 2 (SPEX CertiPrep, Inc.) in $5 \% \mathrm{HNO}_{3}$ matrix, to which the liquid mercury standard in $10 \% \mathrm{HNO}_{3}$ matrix (SPEX CertiPrep, Inc.) was added, were used. As the inner standard, the liquid standard of $10 \mathrm{ppb}$ rhenium was used. Every test was measured three times and the statististically average result was taken into consideration. The calibration of the results of tests was made according to the fully quantative analysis in which the linear correlation, measured with stand, was taken as the starting point through the measured "blank". Ultraclean $2 \%$ of $\mathrm{HNO}_{3}$ was used as a blank. In the taken bone samples the contents of the following chemical elements were detected: $\mathrm{Ca}, \mathrm{V}, \mathrm{Cr}, \mathrm{Mn}, \mathrm{Fe}, \mathrm{Cu}, \mathrm{Zn}, \mathrm{Sr}, \mathrm{Ba}, \mathrm{Hg}$ and $\mathrm{Pb}$. All the detected elements will not be treated below. For the assessent of the quality of the bone material or possible diagenesis the correlation of the contents of iron and strontium were used. If the correlation between $\mathrm{Fe}$ and $\mathrm{Sr}$ is missing, the material is not polluted - the exchange of ions between the soil and the bone tissue has not taken place [13]. In the whole studied material the correlation between $\mathrm{Fe}$ and $\mathrm{Sr}$ was very weak but statistically significant $(\mathrm{r}=0,303$; $\mathrm{P}=0,04)$. If to view the relation between $\mathrm{Fe}$ and $\mathrm{Sr}$ in the studied series, the correlation between Fe and Sr was fully missing in the Tääksi and the Pärnu series (in Tääksi $r=-0.337, \mathrm{P}=0.079$; in Pärnu $\mathrm{r}=0,034, \mathrm{P}=0.857$ ), but it was significant in the Pada series ( $\mathrm{r}=0.538 ; \mathrm{P}=0.002)$.

The Pada cemetery, as well as the Tääksi cemetery, is located in the area of the leached soil which was formed on the carbonate lower stratum and is consequently of neutral reaction [39, 47]. In the neutral environment ions are moving very little and this is why it may be supposed that the exchange of ions between the bone and the soil has been of little importance. Unfortunately, we do not have the data concerning the soil $\mathrm{pH}$ of the Pärnu cemetery. 
In addition to the level of the substrate's $\mathrm{pH}$ level, differences in the preservation of the bone material may be caused by the co-effects of the taphonomic process having taken place in the local microlevel together with the temporal factor. In its turn, the processes depend on the burial rituals. It is very hard to assess the microlevel diagenesis after it had taken place but it deserves mentioning that Pada is the earliest and with the richest grave goods among the studied series. It would explain the weak and significant correlation of $\mathrm{Fe}$ and $\mathrm{Sr}$ and the abnormal contents of some elements in the Pada bones. In the present paper 3 individuals from the Pada series have been left out because in their bones the content of $\mathrm{Cu}$ was over the physiological limit. Abnormal contents of $\mathrm{Cu}$ could have been caused by bronze adornments in the burial.

Statistically significant differences, in the contents of microelements in the bones of men and women and the differences between different series were obtained using the t-test. The sizes of the sample were too small for the analysis of gender differences in the series of the basis of correlations. For the mutual comparison of the studied series the cluster analysis (average linkage method between the groups) was used. For the analysis the contents of $\mathrm{Ba}, \mathrm{Cu}, \mathrm{Pb}, \mathrm{Sr}$, $\mathrm{Zn}$ and $\mathrm{Mn}$ in different groups were used. The data were processed with the software program SPSS 17.0.

\section{RESULTS AND DISCUSSION}

The contents of chemical elements determined in the bones are presented in Table 1 and Table 2. The measurement of the content of calcium (Ca) was carried out with the purpose of assessing the quality of the material under study. In the case of the fully preserved collagen, the content of $\mathrm{Ca}$ in the archaeological bones fluctuates $26 \%-38 \%$ [14]. In the whole archaeological material, studied by us, on average there was $24.95 \%$ of calcium (16.2-34.9\%), the smallest was in Tääksi women (Table 1). In all the groups variation was bigger in women. On the one hand, it may be caused by a bigger diagenesis [44]. On the other hand, the calcium content in the women's bones varies much depending on the physiological satus of the woman's organism. It is known that during the periods of pregnancy, breast feeding and in the end of the fertile age the proportion of $\mathrm{Ca}$ in the bone tissue may decrease. Gender differences in the average contents of $\mathrm{Ca}$ in bones were not statistically significant. 


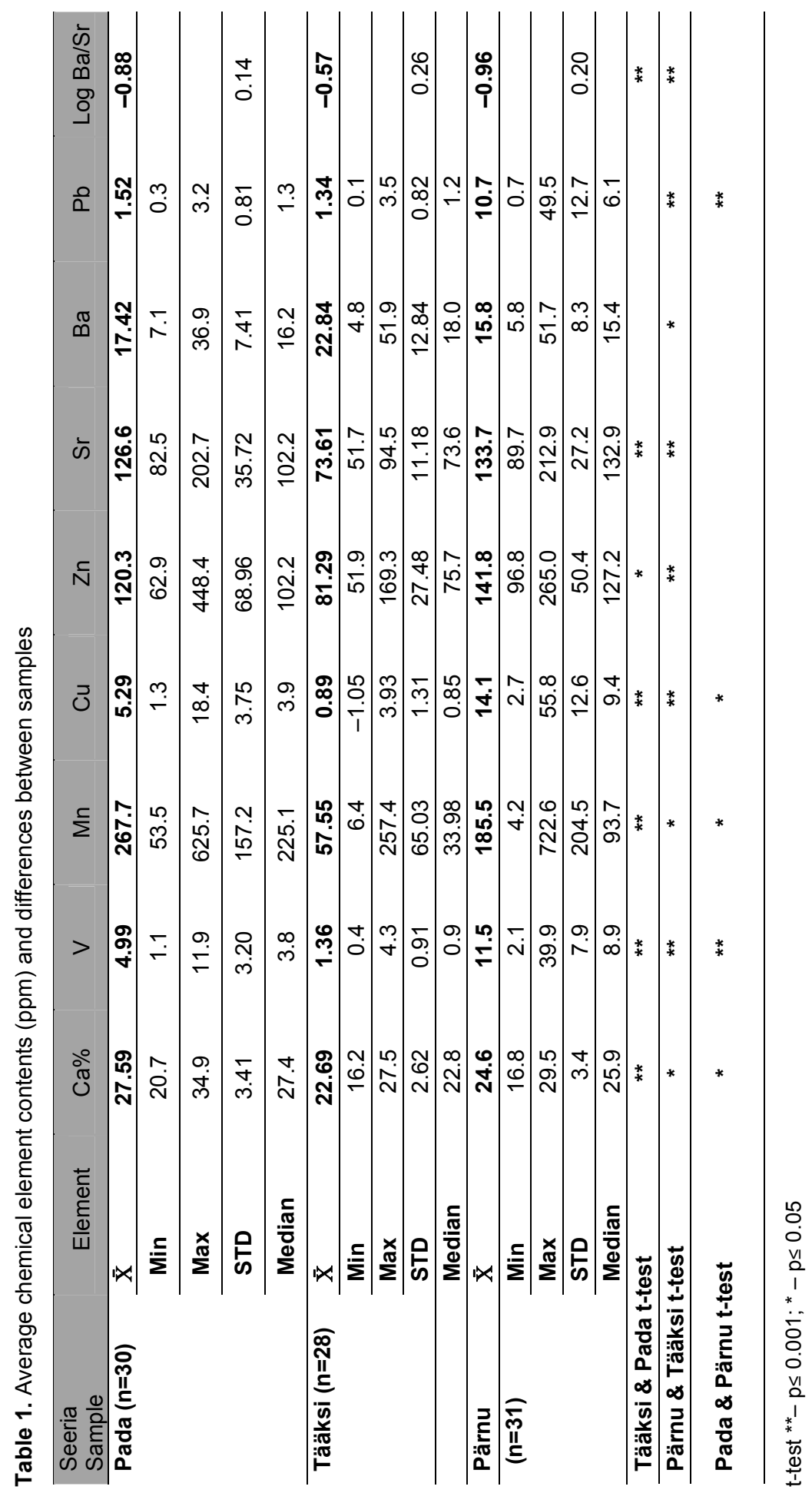




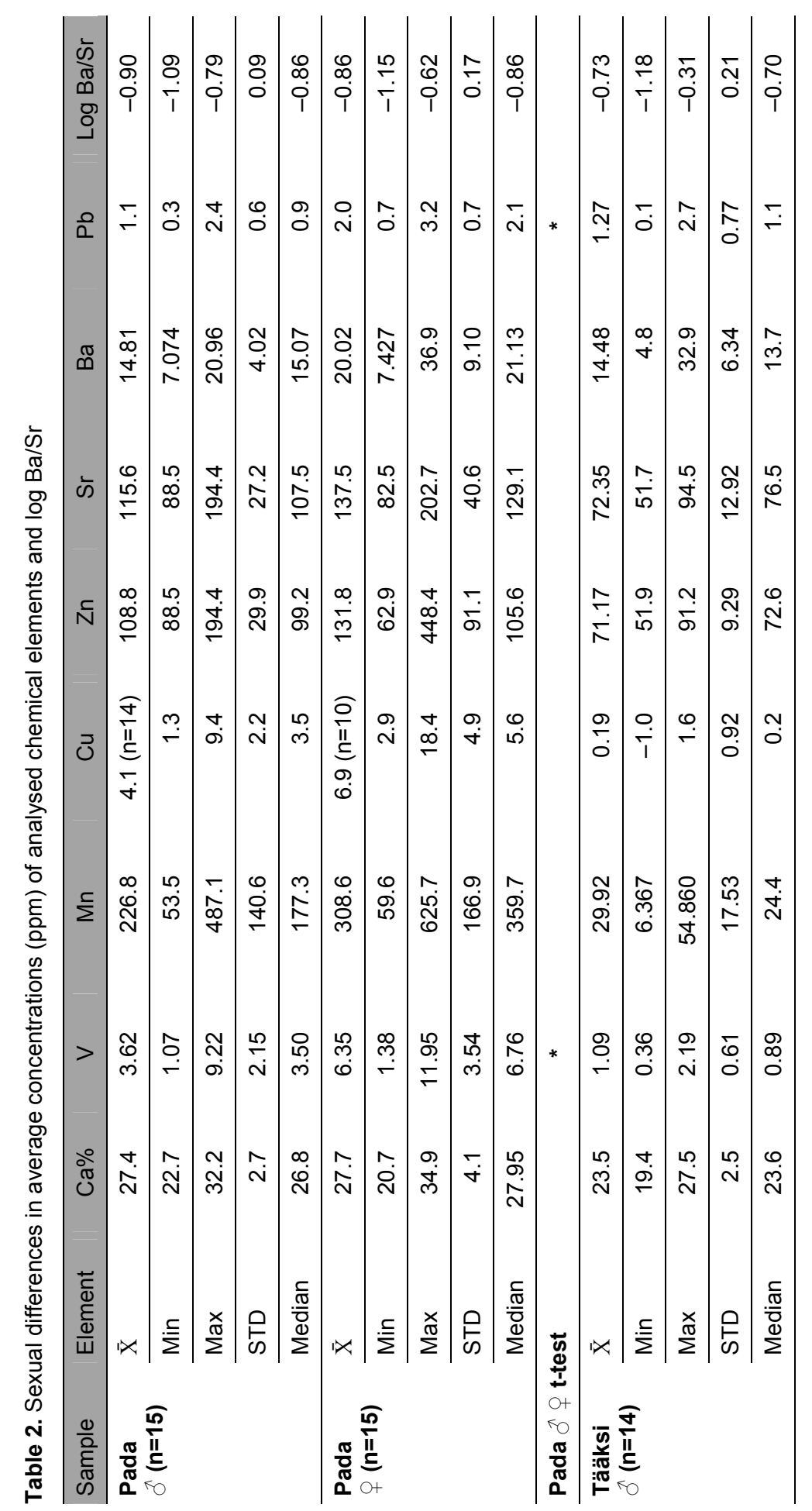




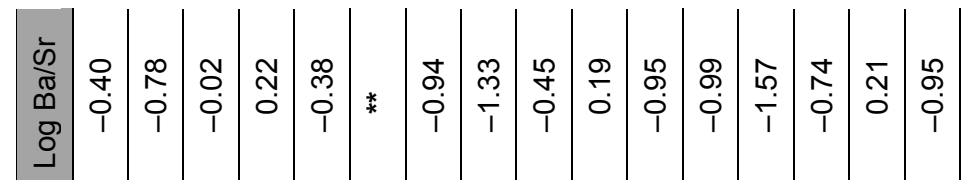

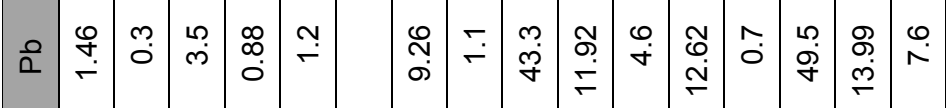

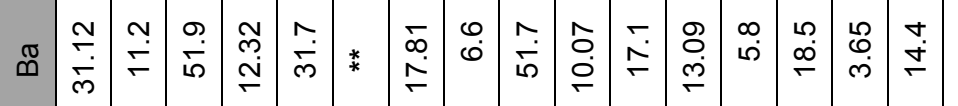

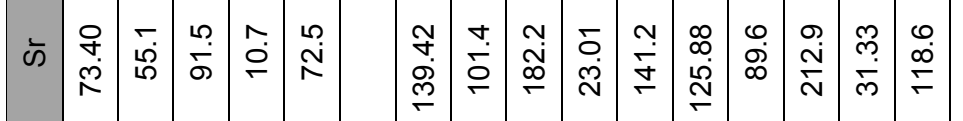

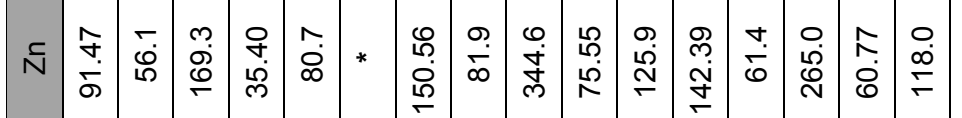

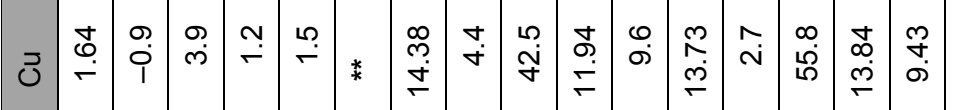

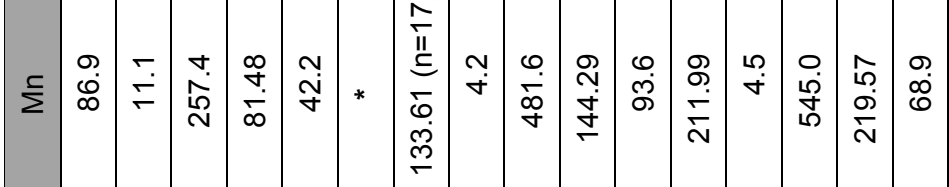

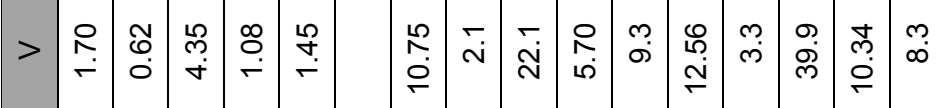

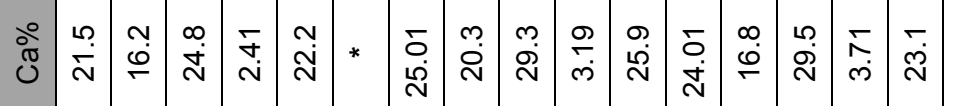

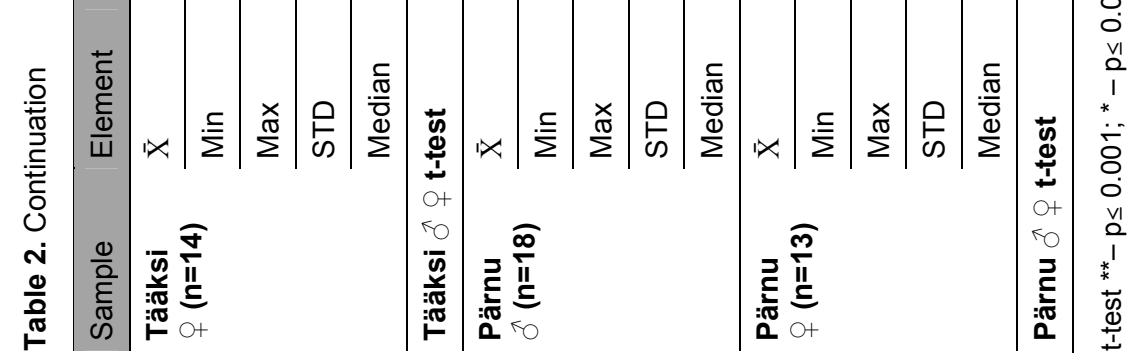


The contents of $\mathbf{M n}, \mathbf{B a}$ and $\mathbf{S r}$ are considered to be the indicators of plant food. The higher the indication, the bigger the plant component in the community's nutrition has been. The manganese (Mn) content varies in a noteworthy way in the Estonian archaeological bones: in the Tääksi material it was between 6-257 ppm, in the Pada material 59.6-625.7 and the Pärnu material 4-723 ppm (Table 1). On the one hand, it gives an idea that possibly the higher values of $\mathrm{Mn}$ in some single individuals are connected with later post-mortem chemical processes having taken place. The pollution of bones with $\mathrm{Mn}$ ions has also been noticed earlier [52]. On the other hand, it is known that plant foodstuffs are the main sources of $\mathrm{Mn}$ while the content of $\mathrm{Mn}$ in the plant is directly caused by the content of $\mathrm{Mn}$ in the soil.

In the Tääksi bones the average content of manganese was the smallest in the studied Estonian series (Tables 1, 2; Figure 2). In the Pada and Pärnu bones it was significantly bigger. Here it can be concluded that more plant food was consumed at Pada and in Pärnu but the content of microelements $(\mathrm{V}, \mathrm{Cu}$, $\mathrm{Zn}$ ) describing meat food, was also bigger at Pada and in Pärnu [6]. In principle, these results are in harmony between themselves because manganese cannot be well assimilated from only the food consisting of plants but its consumption together with animal protein increases the assimilation of manganese significantly [30].

In all the Estonian series there was more manganese in women's bones (Table 2), this difference was statistically significant in the Tääksi series. Similar gender difference has also been found by Latvian researchers [46]. The first hypothesis is that most probably the women consumed more plant food than men. The second hypothesis to explain the higher content of $\mathrm{Mn}$ in the women's bones in comparison with men is caused by the women's physiology. Namely, it is known that if the organism suffers from the lack of iron, it assimilates manganese in bigger quantities [22]. The lack of iron in the organism appear more often in women caused by their physiological specificity. The gender differences of the content of $\mathrm{Mn}$ in all the compared series (Table 2) speak of the possibility of both hypotheses. 


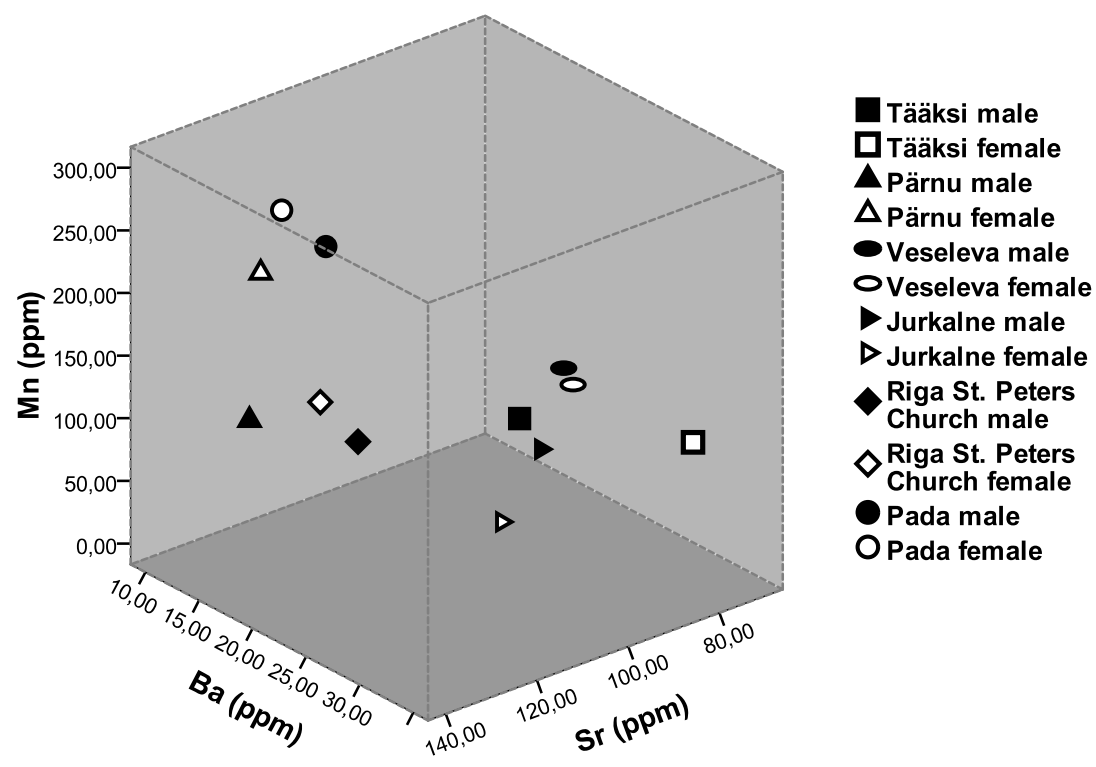

Figure 2. Average concentrations of $\mathrm{Mn}, \mathrm{Ba}$ and $\mathrm{Sr}$ in studied Estonian and comparative Latvian samples (Veseleva, Jurkalne, Riia St. Peters: Rudovica et al 2009).

The contents of barium ( $\mathbf{B a})$ in the Estonian series are relatively similar (Table 1), being in the Pärnu and Pada bones respectively 15.8 and $17.42 \mathrm{ppm}$ and in Tääksi bones $22.84 \mathrm{ppm}$. The gender differences of the content of $\mathrm{Ba}$ are statistically significant both at Pada and at Tääksi which can show the bigger proportion of plant food in the menu of their women. Also, in comparison with Latvia, significant differences between series do not appear (Table 2, Figure 2). Tääksi deserves special mentioning. At Tääksi the contents of $\mathrm{Ba}$ in men and women differ almost 2 times.

The content of strontiumi ( $\mathbf{S r}$ ) in bones is considered to be the indicator of plant food. The situation becomes more complicated in the marine environment because the concentrations of $\mathrm{Sr}$ are bigger in the sea water and the marine food [34].

The content of $\mathrm{Sr}$ in the Tääksi bones was on average $73.6 \mathrm{ppm}$, in the Pada bones $126.58 \mathrm{ppm}$, in the Pärnu bones $133.7 \mathrm{ppm}$ (Table 1). The higher content of strontium in the Pärnu and the Pada bones in comparison with Tääksi may be caused by a higher amount of sea products in their nutrition. The importance of carbonate soils in different areas cannot also be excluded. Both the marine food and the specific features of the soil may cause higher values of $\mathrm{Sr}$ in bone. In the Pada and Tääksi bones the content of Sr was higher in 
women, in Pärnu it was slightly higher in men and the statistically significant gender differences were missing (Table 2, Figure 2).

In the paleodiet research the contents of $\mathrm{Sr}$ are used for distinguishing the marine and the inland nutrition [18]. The studied Estonian series also show that the concentration of strontium in the bones is bigger in the bones of the populations which lived closer to the sea (Table 1). Our reserach shows that $\mathbf{S r}$ is rather connected with the marine origin of food. The contents of $\mathrm{Sr}$ are bigger in the bones from Pärnu and Pada as well as from Riga and Jurkalne in Latvia. The contents of $\mathrm{Sr}$ are smaller in the bones from the burial places more to the inland (Table 2, Figure 2).

\section{$\log \mathrm{Ba} / \mathrm{Sr}$ as the indicator of the origin of food}

In the marine organisms the contents of $\mathrm{Sr}$ are higher while the contents of $\mathrm{Ba}$ are low.

The $\log \mathrm{Ba} / \mathrm{Sr}$ of the population of the village of Tääksi is almost two times higher $(-0.57)$ than in the population of the town Pärnu $(-0.96)$, a rather similar value of $\log \mathrm{Ba} / \mathrm{Sr}(-0.88)$ also characterizes the population of Pada (Table 1). The values of $\log \mathrm{Ba} / \mathrm{Sr}$ refer to the so-called mixed menue of the people of the town of Pärnu and the stronghold of Pada which contained both the inland and the marine food, but in comparison with the village of Tääksi, relatively more marine food was consumed. Gender differences were statistically significant at Tääksi but missing in the groups of Pärnu and Pada. The variability of the $\log \mathrm{Ba} / \mathrm{Sr}$ of the bones of Pada women was notably high as also in the case of the contents of other elements. It may show the different origin of the Pada women (the distance of the place of living from the sea) and the differences in the composition of their food and eating habits. The highest $\log \mathrm{Ba} / \mathrm{Sr}(-0.40)$ value characterizes the women of Tääksi (Table 2, Figure 3 ) who most probably consumed more inland food. Also, the values of $\log \mathrm{Ba} / \mathrm{Sr}$ are high ( -54 to -60$)$ characterizing the village communities Jurkalne and Veseleva. A lower $\log \mathrm{Ba} / \mathrm{Sr}$ characterizes the communites buried to the cemeteries of the Pärnu garrison and St. Peter's church in Riga, which refers to the bigger proportion of marine food in their choice of food (Table 2).

$\mathbf{V}, \mathbf{C u}$ and $\mathrm{Zn}$ are the indicators of meat food or the animal protein in food [13]. Vanadium (V) is plentiful in fish fat but green vegetables are also rich in vanadium [51]. Consequently, vanadium can be rather called an indicator of diversified menu [6]. The $\mathrm{V}$ concentration in the bones of Tääksi is on average $1.36 \mathrm{ppm}$, in the bones of Pärnu there is about 10 times more vanadium - on 
average $11.5 \mathrm{ppm}$, the bones of Pada remain in between these two with the content of $\mathrm{V}$ being $4.99 \mathrm{ppm}$ (Table 1). In the Latvian material V content was not measured [46].

It has been observed that if the determined $\mathrm{Zn}$ and $\mathrm{Cu}$ indicators are high, then as a rule, together with them the $\mathrm{V}$ indicator is high because animal fat contains $\mathrm{V}[13]$.
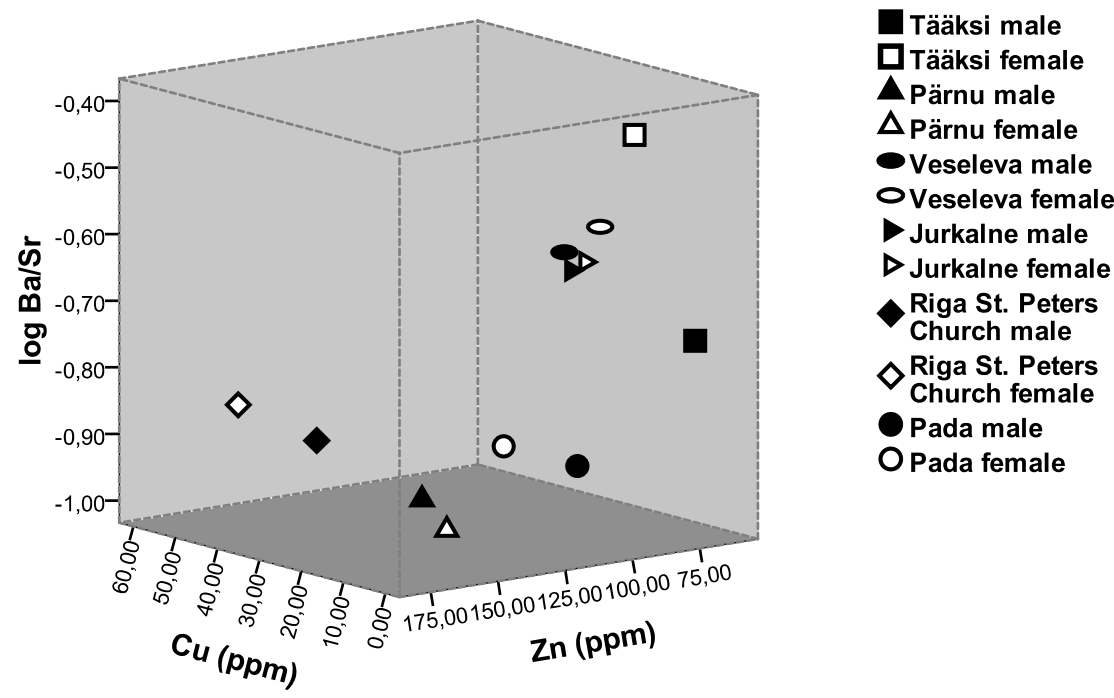

Figure 3. Average concentrations of $\mathrm{Cu}, \mathrm{Zn}$ and average log $\mathrm{Ba} / \mathrm{Sr}$ in studied Estonian and comparative Latvian samples (Veseleva, Jurkalne, Riia St. Peters: Rudovica et al 2009).

The average content of copper $(\mathbf{C u})$ in the Pärnu series was significantly higher $(14.1 \mathrm{ppm})$ than in the Pada $(5.29 \mathrm{ppm})$ and the Tääksi (0.89 ppm) series. The higher content of copper in the Pärnu bones can be connected with the bigger importance of meat and fish in the diet. Considering the eating habits in those times, we may suppose that the proportions of crustaceans in the menu were relatively small. In the women's bones the content of copper was bigger at Pada and Tääksi, in Tääksi gender difference was statistically significant (Tables 1, 2; Figure 3).

In the studied Estonian series the content of $\operatorname{zink}(\mathbf{Z n})$ was the lowest at Tääksi (81.29 ppm). The content of zink in the bones of Pada and Pärnu was higher - 120.35 and 141.80 ppm - respectively, which refers to the bigger 
proportions of meat and marine food in the nutrition of the Pada and the Pärnu communities (Table 1).

At the same time one should be careful in interpreting the content of zink because the $\mathrm{Zn}$ content in women's bones grows with age, in men's bones it decreases $[38,9]$. In the bones of the older women of Tääksi in some individuals there were suprisingly high contents of zink which raised the average content of zink in Tääksi women - in women $91.5 \mathrm{ppm}$, in men 71.1 (Table 2). Also, it should be remembered that a bigger part of zink in the bones is connected rather to the organic part of the bone tissue than the inorganic part. In the case of archaeological bones, the loss of the organic part is possible, which may make the interpretation of zink more difficult [42].

In comparison with Latvian trace element analyses [46] $\mathrm{Zn}$ and $\mathrm{Cu}$ values are higher in the archaeological bones of the towns of Riga and Pärnu (Table 2, Figure 3). On the one hand, the people buried in the cemetery of the Pärnu garrison and St. Peter's church in Riga represent the town populations at the sea. On the other hand, it is known that mainly the middle class of German origin was buried in the St. Peter's church [46] and the cemetery of St. John's church in Pärnu was mainly used by the Russian garrison. The menu of these communities with relatively higher social status most probably contained more meat and marine food. Tääksi, Veseleva and Jurkalne, represent village communities in the Middle Ages and the Early Modern Times. In their bones the contents of $\mathrm{Cu}$ and $\mathrm{Zn}$ are lower which probably refers to the smaller proportion of meat and marine food in their menu (Table 2, Figure 3). The group is characterized by the inland food and it is most probably of major plant composition. In the case of the studied indicators $(\mathrm{Zn}$ and $\mathrm{Cu}$ ) the community buried to the Pada cemetery is different from the seaside towns and inland village communities. It may be caused by the heterogenity of the community (different geographical origin of individuals, social status) and the connected differences in nutrition. It should be born in mind that the Pada community is the earliest in time, originating from the final period of ancient times when the climatic conditions and the social order were different.

In the bones of the people who lived in town in the Middle Ages and the Early Modern Times lead $(\mathbf{P b})$ is usually in a bigger quantity than in the bones of the rural people. Appearance of lead in the organism is explained by the facts that the kitchen vessels were covered with the glazing containing lead and the drinking water coming from the pipelines containing lead $[49,17]$. In the Pärnu bones there was significantly more lead than in the bones of Pada and 
Tääksi and the differences were statistically significant (Table 1). It may be connected with the style of life in a town of the Early Modern Times but at the same time we cannot exclude the post-mortem pollution of bones of Pärnu with $\mathrm{Pb}$ ions which has also been found even earlier in the case of archaeological materials [52].

The comparative research of nutrition in the rural and town popultions in Estonia in the $12^{\text {th }}-18^{\text {th }} \mathrm{cc}$. showed that the higher contents of $\mathrm{Pb}, \mathrm{Sr}, \mathrm{Zn}$ and $\mathrm{Cu}$ in the bones were characteristic of the town population. In the bone material from the town of Pärnu the levels of $\mathrm{Pb}, \mathrm{Sr}, \mathrm{Zn}$ and $\mathrm{Cu}$ are higher than in the material of Tääksi or Pada [6]. The same trend (Table 2, Figure 3) is also demonstrated by the analysis of the Latvian $13^{\text {th }}-17^{\text {th }} \mathrm{cc}$. material [46].

The Estonian and the Latvian series were compared with the method of cluster analysis (average linkage, Euclidean distance) using the contents of the following chemical elements in bones: $\mathrm{Mn}, \mathrm{Ba}, \mathrm{Sr}, \mathrm{Zn}, \mathrm{Cu}$ and $\mathrm{Pb}$. According to the content of chemical elements, the studied groups can in general be divided into two clusters, which join between themselves at a rather high level (Table 3, Figure 4). The first, the biggest cluster unites the most similar groups - medieval and early modern Estonian and Latvian rural populations (Tääksi, Veseleva and Jurkalne). On the other side the town populations of the same time join them (the town of Riga and men from Pärnu). The second cluster unites from the compared series the ancient Pada and the group of women from the town of Pärnu having relatively similar indicators. Clusters are different mainly because of the contents of strontium, manganese and barium. The groups united in the first cluster are characterized by a smaller content of $\mathrm{Sr}$ and $\mathrm{Mn}$ and a bigger content of Ba (Table 3 ).

Table 3. K-means cluster analysis final cluster centres

\begin{tabular}{lcc}
\hline \multicolumn{3}{c}{ Cluster Centers } \\
\hline \multicolumn{3}{|c}{ Cluster } \\
\hline $\mathrm{Zn}$ & 1 & 2 \\
\hline $\mathrm{Sr}$ & 120.47 & 127.70 \\
\hline $\mathrm{Mn}$ & 96.46 & 126.36 \\
\hline $\mathrm{Ba}$ & 84.50 & 249.17 \\
\hline $\mathrm{Cu}$ & 21.04 & 15.98 \\
\hline $\mathrm{Pb}$ & 11.71 & 8.26 \\
\hline
\end{tabular}




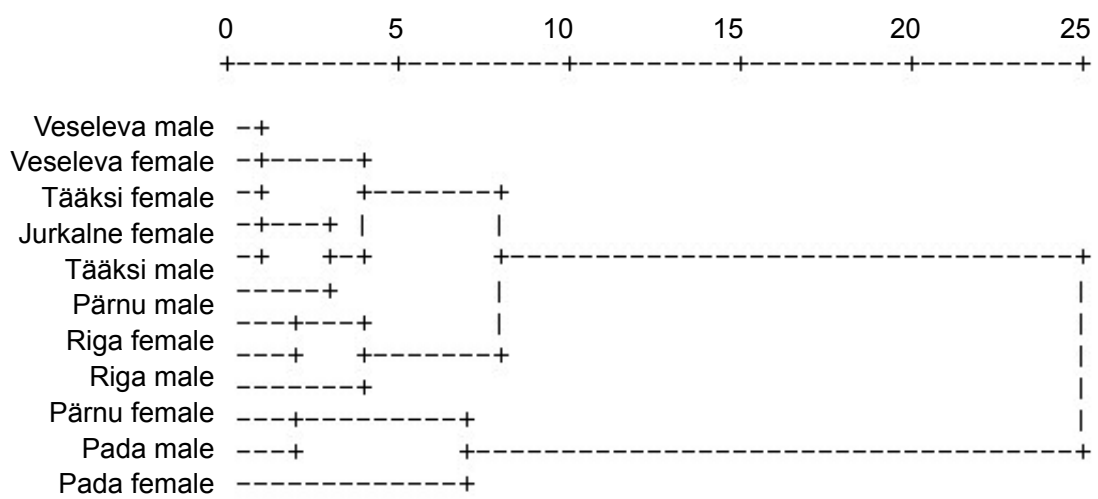

Figure 4. Hierarhical cluster analysis (Average Linkage Cluster Analysis with squared Euclidean distances) dendrogram based on $\mathrm{Ba}, \mathrm{Cu}, \mathrm{Pb}, \mathrm{Sr}, \mathrm{Zn}, \mathrm{Mn}$ contents.

\section{CONCLUSIONS}

The communities buried to the cemeteries of the Pärnu garrison and St. Peter's church in Riga have certain similar nutrition indicators, $\log \mathrm{Ba} / \mathrm{Sr}$ is relatively low referring to the bigger proportion of marine food in comparison with Latvian and Estonian village communities. Also, the values of $\mathrm{Zn}$ and $\mathrm{Cu}$ in the archaeological bones of the towns of Riga and Pärnu are higher which are the indicators of the proportions of both meat and seafood in nutrition. On the one hand, the communities buried to the cemetery of the Pärnu garrison and into St. Peter's church in Riga were of a higher social status but on the other hand, both are the town populations at the sea.

Tääksi, Veseleva and Jurkalne represent medieval and early modern village communities and from a separate group on the basis of nutriton indicators. The group is characterized by the food from the inland and most probably the smaller proportions of meat in the menu. Concerning the studied indicators, the community buried to the Pada cemetery is different from the communities of the seaside towns and inland villages. It may be caused by the heterogenity of the community (the different geographical origin of individuals, their social status) and in this connection their nutrition is different. We should bear in mind that the Pada comunity is the oldest in time, originating from the final period of ancient times when climatic conditions and the social order were different. It should be mentioned that in the contents of copper and zink there were certain differences between the Latvian and the Estonian series. As a rule, the content of these elements is bigger in men but in the Tääsi and the Pada 
series it is the other way round. What such irregularity is caused by is difficult to explain at the present stage of research.

\section{ACKNOWLEDGEMENT}

The study was undertaken in the framework of the target funded research project of the Estonian Government (SF0130012s08).

\section{REFERENCES}

1. Allmäe R. (1998). Tääksi 14.-18. sajandi populatsiooni demograafiline analüüs ja kehapikkuse rekonstrueerimine. Muinasaja Teadus 5, Loodus, inimene ja tehnoloogia: interdistsiplinaarseid uurimusi arheoloogias, 163-187.

2. Allmäe R. (2009). Composition of urban population of Pärnu in the $16^{\text {th }}-18^{\text {th }}$ centuries. Papers on Anthropology, XVIII, 38-48.

3. Allmäe R., Limbo J. (2008). 16.-18. sajandi Pärnu garnisoni kalmistule maetute antropoloogiast. Pärnumaa 1. köide. Loodus. Aeg. Inimene. Eesti Entsüklopeediakirjastus, Tallinn, 369-387.

4. Allmäe R., Limbo J. (2010). Skeletal stress-markers in the Early Modern town of Pärnu, Estonia. Papers on Anthropology, XIX, 29-48.

5. Allmäe R., Verš E. (2011). Pilguheit esivanemate toidulauale - kas liha-, kala- või taimesööjad? In: Verš E., Preeden U., Lang L. (eds.) Maa ressursid. Schola Geologica, Tartu. Eesti Looduseuurijate Selts, 44-55.

6. Allmäe R., Limbo-Simovart J., Heapost L., Verš E. (2012). Arheoloogilised inimluud toitumisuuringute allikana. Muinasaja Teadus 23, Loodus, inimene ja tehnoloogia: interdistsiplinaarseid uurimusi arheoloogias. In print.

7. Armelagos G. J., Alcom M., Martin D., Vangreven D. P. (1989). Factors affecting elemental and isotopic variation in prehistoric human skeletons. In: Price T.D. (ed.) The Chemistry of Prehistoric Human bone. Cambridge: Cambridge University Press, 230-244.

8. Avioli L. V. (1988). Calcium and Phosphorus. In: Shils M. E., Young V. R. (eds.) Modern Nutrition in Health and Disease, $7^{\text {th }}$ ed. Lea and Febiger, Philadelphia, 142-158.

9. Benfer R. (1995). Age of Pregnancies and Age of Weaning from Prehistoric Bone: Are Sr and Zn Indicators? Am. J. Physic. Anthrop, Supplement 20, 89-90.

10. Bentley R. A. (2006). Strontium isotopes from the earth to the archaeological skeleton: a review. Journal of Archaeological Method and Theory, 13, 135-187.

11. Bronner F. (2008). Metals in bone: Aluminium, Boron, Cadmium, Cromium, Lanhanum, Lead, Silicon, and Strontium. In: Bilezikian J. P., Lawrence G. R., Martin T. J. (eds.) Principles of Bone Biology. Third edition. Volume 1. Elsevier, USA, 515-532. 
12. Brown A. (1973). Bone strontium as dietary indicator in human skeletal populations. PhD dissertation. University of Michigan.

13. Buikstra J. E., Frankenberg S., Lambert J. P., Xue L. A. (1989). Multiple elements: Multiple expectations. In: Price T. D. (ed.) The Chemistry of Prehistoric Human bone. Cambridge: Cambridge University Press, 155-210.

14. Burton J. H. (2008). Bone chemistry and trace element analysis. In: Katzenberg M. A., Saunders, S. R. (eds.) Biological Anthropology of the Human Skeleton. Wiley-Liss, USA, 443-460.

15. Burton J. H., Price T. D. (1990). The ratio of barium to strontium as a paleodietary indicator of consumption of marine resources. Journal of Archaeological Science, 17: 5, 547-557.

16. Burton J. H., Price T. D., Cahue L., Wright L. E. (2003). The use of barium and strontium abundances in human skeletal tissues to determine their geographic origins. International Journal of Osteoarchaeology, Special Issue: Bone Chemistry. 13: 1-2, 88-95.

17. Celminš A. (1998). Zemē apslēptā pilsēta. Dizaina un drukas apgāds, Riga.

18. Connor M., Slaughter D. (1984). Diachronic study of Inuit diets utilising trace element analysis. Arctic Anthropology 21, 123-134.

19. Edward J., Benfer R. A. (1993). The Effects of Diagenesis on the Paloma Skeletal Material. In: Sanford M. K. (ed.) Investigations of Ancient Human Tissue: Chemical Analyses in Anthropology. Philadelphia: Gordon and Breach, 183-268.

20. Ezzo J. A. (1994). Putting the "chemistry" back into archaeological bone chemistry analysis: modeling potential paleodietary indicators. J. Anthropol. Archaeol. 13, 1-34.

21. Fabig A., Herrmann B. (2002). Trace elements in buried human bones: intrapopulation variability of $\mathrm{Sr} / \mathrm{Ca}$ and $\mathrm{Ba} / \mathrm{Ca}$ ratios - diet or diagenesis? Naturwissenschaften, 89, 115-119.

22. Finley J. W., Johnson P. E., Johnson L. K. (1994). Sex affects manganese absorption and retention by humans from a diet adequate in manganese. American Journal of Clinical Nutrition, 60:6, 949-955.

23. Gilbert R. I. (1975). Trace elements analyses of three skeletal Amerindian populations at Dicson mounds. $\mathrm{PhD}$ dissertaion, University of Massachusetts, Amherst.

24. Gilbert R. I. (1985). Stress, paleonutritiona nd trace elements. In: Gilbert R. I., Milke J. H. (eds.) The analysis of prehistoric diets. Academic Press, 339-357.

25. Grupe G. (1988). Impact of the choice of bone samples on trace element data in excavated human skeletons. Journal of Archaeological Science, 15: 2, 123-129.

26. Hasan H. (2008). Manganese. Understanding the Elements of the Periodic Table. The Rosen Publishing Group, Inc. New York. 
27. Heapost L. (2002). Pada 12.-13. sajandi kalme osteomeetria ja rekonstrueeritud somatomeetria. Eesti Antropomeetriaregistri Aastraamat 2002. Tartu Ülikooli Kirjastus, 39-46.

28. Hedges R. E. M., Millard A. R., Pike, A. W. G. (1995). Measurements and relationships of diagenetic alteration of bone from three archaeological sites. Journal of Archaeological Science, 22, 201-9.

29. Jürjo, I. (2010). Pärnu ja Pärnumaa 18. sajandil. In: Vunk, A. (ed.) Pärnumaa. Loodus. Aeg. Inimene. Eesti Entsüklopeediakirjastus, 114-123.

30. Kies C., Aldrich K. D., Johnson M. J., Creps C., Kowalsi C., Wang, R. H. (1987). Manganese availability for humans, effect of selected dietary factors. In: Kies C. (ed.) Nutritional Bioavailability of Manganese. American Chemical Society, Washington, DC.

31. Klepinger L. L. (1993). Culture, health and chemistry: a technological approach to discovery. In: Sandford M. K. (ed.) Investigations of ancient human tissue. Gordon and Breach Science Publisher, 167-80.

32. Küng E. (2010). Rootsi aeg 1600-1609 ja 1617-1710. In: Vunk A. (ed.). Pärnumaa. Loodus. Aeg. Inimene. Eesti Entsüklopeediakirjastus, 95-109.

33. Lambert J. B., Szpunar C. B., Buikstra, J. E. (1979). Chemical analysis of excavated human bone from Middle and Late Woodland sites. Archaeometry, 21,115-129.

34. Leach F., Quinn C. J., Morrison J., Lyon G. (2003). The use of multiple isotope signatures in reconstructing prehistoric human diet from archaeological bone from the Pacific and New Zealand. New Zealand Journal of Archaeology, 23, 3198.

35. Lidén K. (1995). Prehistoric Diet Transitions. An Archaological perspective. PhD Dissertation. Stockholm University.

36. Limbo J. (2004). Pada kalmistu indiviididel esinevad hambapatoloogiad (XIIXIII saj.). Eesti Arholoogiaajakiri, 8:1, 49-75.

37. Limbo J. (2009). Dental pathologies and linear enamel hypoplasia in Pärnu St. John's church cemetery $\left(16^{\text {th }}-18^{\text {th }}\right)$ skeletons. Papers on Anthropology, XVIII, 234-249.

38. Magee B. J., Sheridan S. G., Van Gerven D. P., Greene, D. L. (1994). Elemental analysis of Mesolithic bone from Wadi Halfa: A diagenetic and dietary investigation of permineralized human remains. Denver CO, March 30-April 2. Amer. Journal of Physical Anthropology, 18:134.

39. Maps of the Estonian Land Board (2012). http://geoportaal.maaamet.ee/est/Kaardiserver-p2.html

40. Nielsen-Marsh C. M., Smith C. I., Jans M. M. E., Nord A., Kars H., Collins M. J. (2007). Bone diagenesis in the European Holocene II: taphonomic and, environmental considerations. Journal of Archaeological Science 34, 1523-1531.

41. Pate D. F. (1994). Bone chemistry and paleodiet. Journal of Archaeological Method and Theory 1, 161-209. 
42. Pearsall D. M. (1989). Paleoethnobotany: A Handbook of Procedures. Academic Press.

43. Pollard M., Batt C., Stern B., Young S. M. M. (2007). Analytical chemistry in archaeology. Cambridge University Press, New York.

44. Price T. D. (1989). Multi-element studies of diagenesis. In: Price T. D. (ed.) The Chemistry of Prehistoric Human bone. Cambridge: Cambridge University Press, $126-154$.

45. Price T. D., Blitz J., Burton J., Ezzo J. A. (1992). Diagenesis in prehistoric bone: Problems and solutions. Journal of Archaeological Science, 19:5, 513-529.

46. Rudovica V., Viksna A., Katkevich J., Zarina, G. (2009). Some aspects of diet of the $13^{\text {th }}-17^{\text {th }}$ century population of Latvia. Papers on Anthropology, XVIII, 328338.

47. Reintam L. (2012) Eesti mullad. http://www.botany.ut.ee/mullaveeb/sisu/yldine.html 15.05.2012

48. Smith C. I., Nielsen-Marsh C. M. Jans M. M. E., Collins M. J. (2007). Bone diagenesis in the European Holocene I: patterns and mechanisms. Journal of Archaeological Science, 34, 1485-1493.

49. Smrčka V. (2005). Trace elements in bone tissue. The Karolinum Press, Prague.

50. Sokolovski 1990 = Соколовский В. (1990). Средневековое деревенское кмаАбище в Тяэкси. Eesti TA Toimetised, Ühiskonnateadused, 4, 412-422.

51. Söremark R. (1967). Vanadium in Some Biological Specimens. Journal of Nutrition, 92:2, 183-90.

52. Zapata J., Pérez-Sirvent C., Martínez-Sánchez M. J., Tovar, P. (2006). Diagenesis, not biogenesis: Two late Roman skeletal examples. Science of the Total Environment, 369, 357-368.

53. Tamla T. (2010). Aruanded Pada maa-aluse kalmistu kaevamistest Rakvere rajoonis Viru-Nigula kolhoosis (Viru-Nigula Kihelkond. Pada asundus; tänapäeval Viru-Nigula vald, Pada küla) aastatel 1987-1989. Käsikirjad 1-103, nr 49-51, in TLÜ AI Fund.

54. Wilson L., Pollard M. (2002). Here today, gone tomorrow? Integrated experimentation and geochemical modeling in studies of archaeological diagenetic change. Acc. Chem. Res., 35, 644-51.

\section{Address for correspondence:}

Raili Allmäe

Department of Archeobiology and Ancient Technology

Institute of History

Tallinn University

Rüütli 6, Tallinn 10130, Estonia

E-mail: raili.allmae@ai.ee 